Ana JOVIĆ-LAZIĆ, Ph.D. ${ }^{1}$

\title{
ALIGNMENT OF THE REPUBLIC OF SERBIA WITH THE COMMON FOREIGN, SECURITY AND DEFENSE POLICY OF THE EU: OBLIGATIONS, ACHIEVEMENTS, AND CHALLENGES ${ }^{2}$
}

https://doi.org/10.18485/iipe_balkans_rssc.2020.ch19

\begin{abstract}
As an EU candidate country, Serbia has obligations to show its willingness to align with the Union's common positions and joint actions in the CFSP/CSDP, support its positions in international organizations, take part in EU military and civil missions, and impose sanctions and other restrictive EU measures. Explanatory and bilateral screening meetings between Serbia and the European Union in the area of the Common Foreign, Security and Defense Policy were held in 2014. However, the European Commission Screening Report for Chapter 31, which covers this area, has not yet been adopted. Meanwhile, relations between the European Union and the Russian Federation have been significantly damaged by the Ukrainian crisis, and mutual sanctions were imposed. In such a complex international environment, Serbia wants to demonstrate its commitment to European integration while trying not to disrupt traditionally good relations and political and economic cooperation with Russia. Apparently, the consequences of the changes in international relations on a global level have affected the process of Serbia's alignment with the EU in the area of the Common Foreign, Security, and Defense Policy. Unfortunately, if the current state of affairs persists, this could affect the overall integration process and Serbia's European perspective.
\end{abstract}

Keywords: Republic of Serbia, European Union, EU candidate country, accession negotiations, CFSP/CSDP, national interest, Russia.

\footnotetext{
${ }^{1}$ Research Fellow, Institute of International Politics and Economics, Belgrade, Serbia. E-mail: anajovic@diplomacy.bg.ac.rs.

2 The paper presents findings of a study developed as a part of the research project "Serbia and challenges in international relations in 2020", financed by the Ministry of Education, Science, and Technological Development of the Republic of Serbia, and conducted by Institute of International Politics and Economics, Belgrade.
} 


\section{INTRODUCTORY REMARKS}

A reliable enlargement policy of the European Union is crucial for continuing the reform process started in the countries concerned, as well as to the public support of the Member States for the enlargement process. The Republic of Serbia's strategic goal to become a full member of the European Union was confirmed by applying for membership on 22 December 2009, and it was granted EU candidate status on 1 March 2012. The accession negotiations of the Republic of Serbia with the European Union were formally opened in January $2014 .^{3}$

This paper examines the alignment of the Republic of Serbia with the European Union in the field of the Common Foreign, Security and Defense Policy. In doing so, it analyzes how these relations have evolved since Serbia was granted candidate status for EU membership and how these relations have changed since the outbreak of the Ukrainian crisis. In this context, some of the reasons for the deadlock in the negotiations between Serbia and the EU in the field of the Common Foreign, Security and Defense Policy, as well as possible ways of overcoming them, were highlighted. In order to contribute to further discussions on this topic, a brief overview of Serbia's EU accession negotiations and the basic elements of the CFSP/CSDP were given first, with a focus on the innovations introduced by the Treaty of Lisbon and a Global Strategy for the European Union's Foreign and Security Policy. Special consideration was given to Serbia's status as an EU candidate country and its engagement in the EU Common Foreign, Security and Defense Policy. To determine the quality and level of integration with the EU in this area, the European Commission's annual reports on Serbia have been analyzed. Attention has been paid only to those parts of the Reports related to Chapter 31, starting from 2012, that is, from the moment Serbia received the status of the official EU candidate. First, steps and measures implemented by Serbia to align its foreign and security policy with the Common Foreign, Security and Defense Policy of the EU were identified. Thereafter, key challenges and constraints regarding the alignment in this area were addressed. To this end, the National Security Strategy and Defense Strategy of the Republic of Serbia and the National Programme for the Adoption of the acquis, besides the annual progress reports of the European Commission, have been examined. The analysis of these documents sought to identify and determine the key

\footnotetext{
${ }^{3}$ The negotiation process is a period during which an EU candidate country aligns its national legislation with the acquis communautaire to be ready for full membership.
} 
reasons why Serbia's compliance with EU Council decisions and declarations in the area of CFSP/CSDP is in constant decline, although EU membership is a foreign policy priority of the country. On this occasion, the international context was also taken into account, i.e., the fact that the disruption of relations between the European Union and the Russian Federation led to a decrease in the degree of alignment with EU measures in the area of CFSP/CSDP. This has affected, inter alia, Serbia's international position, which was manifested by the apparent stalemate in negotiations with the EU on Chapter 31. However, it should not be overlooked that such a situation was a consequence of the fact that Serbia did not adapt its policy to the EU sanctions against Russia, but also the restrictive measures against China, Venezuela, and some countries in the African continent. Bearing in mind that in official documents adopted by the RS Government this policy has been explained by the need to maintain good relations with countries that support the protection of the territorial integrity and sovereignty of the country and its position on the status of Kosovo, it can be expected that Serbia's adjustment to the Common Foreign, Security and Defense Policy will remain very demanding. Finally, the need to obviate this negotiation deadlock through closer and more open cooperation and engagement of both Serbia and the European Union was highlighted.

\section{OBLIGATIONS}

To meet the membership criteria, Serbia is required to align its laws and policies with the acquis communautaire. The accession negotiations are not negotiations in the true sense of the word because the content of the EU acquis is not negotiated since the candidate country is obliged to adopt and fully apply them. ${ }^{4}$ (Međak, 2016; Ateljević, Forca, Zupac, 2015) There is no exception to the Common Foreign, Security and Defense Policy. In fact, this area is becoming an increasingly important part of EU conditionality. The negotiating framework provides, inter alia, that the candidate country must gradually align its foreign policy positions with the other EU Member States

\footnotetext{
${ }^{4}$ The acquis communautaire contains, inter alia, the objectives and principles upon which the Union is founded, and the future Member State is expected to uphold the values on which the Union rests. Besides, the EU accession implies the candidate country is gradually aligning with the EU policies and legal framework. This is necessary not only for the candidate country to join the Union but also to function effectively in the EU legal order upon accession.
} 
and follow a specific direction of the EU foreign policy. This should enable the foreign policy of the former candidate country to be fully harmonized with the EU foreign policy when it becomes a full member. That principle implies the candidate country must take care that its foreign policy does not conflict with the EU Common Foreign, Security and Defense policy. ${ }^{5}$

Over time, the European Union has established a framework for increasing competence and capacity development in the area of the Common Foreign, Security and Defense Policy (Jović-Lazić and Lađevac, 2008; Jović-Lazić, 2006). The Treaty of Lisbon represents the latest step towards the institutionalization of the EU foreign policy and the CSDP (Đurđević-Lukić, 2010; Novičić, 2010; Prolović, 2010). The EU is trying to find its place in the changed world order, and this is evident in the area of foreign and security policy, whose importance is reinforced by the Treaty of Lisbon. With the new institutional set-up, the Union gained legal personality, and the High Representative for Foreign Affairs and Security Policy became the Vice-President of the Commission simultaneously. The European External Action Service is established as the Union's diplomatic service composed of representatives of the Commission, the General Secretariat of the Council and staff appointed by the Member States. Presently, EU Delegations around the world ensure the presence, diplomatic, and political activities of the Union (Brommesson D. and Ekengren A, 2020, pp. 193-195). The changes introduced by the Treaty of Lisbon were intended to enable the EU to lead a more coherent foreign politics. It introduced a 'mutual assistance clause' implying that in cases of armed aggression, an EU Member State under attack may seek assistance from the other Member States, which, in accordance with the UN Charter and their obligations as NATO members, would be obliged to assist with all means at their disposal. This article also states the above provisions do not call into question the'specific character of the security and defence policy of certain member states', such as the neutral status of one of them (Article

\footnotetext{
${ }^{5}$ The harmonization process involves the progressive alignment with the EU acquis in the area of CFSP/CSDP, which comprises international agreements, decisions and conclusions of the Foreign Affairs Council and the Council of the European Union, as well as the foreign policy declarations adopted thereunder. In this way, the EU defines its relation to certain issues. These acts lead to joint activities, measures and unique EU diplomatic actions which include, inter alia, the imposition of sanctions and restrictive measures. Besides enforcing UN sanctions, the European Union independently applies restrictive measures most often to protect the European values and principles that govern it, and which are enshrined in its founding acts.
} 
42(7) TEU). In addition, mutual assistance involves not only defense but also civilian and military assistance from the other EU Member States. The Treaty of Lisbon also provides for a 'solidarity clause' which states that the EU and its Member States must act together in a spirit of solidarity if a Member State is the object of a terrorist attack or the victim of a natural or man-made disaster (Article 222 TFEU). Finally, it is interesting to note, the Treaty of Lisbon clearly insists on the unity of the Member States, emphasizing that the Member States 'actively and unreservedly' support the Union's foreign and security policy 'in a spirit of loyalty and mutual solidarity' and will be consistent with the Union's activities in this field. The Member States should also refrain from any activities contrary to the Union's interests or which might hinder its 'efficiency as a cohesive force' in global politics (Article 24(3) TEU). Thus, as can be seen from an analysis of these provisions, consistency in the EU internal and foreign policy is considered as crucial for a more coherent, effective and credible EU foreign and security policy, while the Member States are expected to speak with one voice and pursue the solidarity-based policy.

The main interests and principles on which the EU should base its further presence and activities in the world are outlined in the Global Strategy for Foreign and Security Policy from 2016. This document starts from the fact that the international environment has changed and indicates the danger that the EU as a project that brought peace, stability, and prosperity could be called into question. It is said to be threatened by the various challenges, instabilities and crises that the EU faces, both domestically and internationally. These changes affect, inter alia, the Union's need to adjust its internal and foreign policies and to act jointly to protect its principles, values, and interests in the world (Barbé and Morillas, 2019, pp. 753-754). The main foreign policy priority of the EU is, first of all, preserving its security, while the Member States are expected to pursue the policy based on mutual assistance and solidarity, which is an integral part of the founding treaties (EU GS, 2016, pp. 9-10). ${ }^{6}$

\footnotetext{
${ }^{6}$ The EU also expresses its clear intention to increase its contribution to the collective security of Europe by working closely with partners, starting with NATO. One of the foreign policy priorities is the integrated approach to conflicts, which provides the EU is actively involved in all stages of the conflict cycle: it works on prevention, reacts responsibly and decisively to crises, invests in stabilization, and avoids premature termination of engagement in the event of a new crisis. Finally, this document states that the EU is committed to a global order based on international law, human rights protection, and sustainable development (EU Global Strategy, 2016, pp. 9-10).
} 
Thus, the size and scope of EU external actions outlined in the Treaty of Lisbon and the Global Strategy contradict the frequent, open remarks of Eurosceptics claiming the EU has no foreign policy at all. It is indisputable the Union has a clear intention to become a more coherent international actor and decision-maker in the area of foreign and security policy, thereby increasing its effectiveness in dealing with international problems and managing international crises. The EU wants to be at the forefront of global efforts to build stability and develop multilateral cooperation (Davis Cross, 2016, p. 42). For example, the Union today not only coordinates its foreign policy internally but also externally with non-member countries. In multilateral forums, the European Union encourages non-EU countries to join its agreements, thereby demonstrating their adherence to EU norms and standards. Although the EU cannot and does not impose legal sanctions in the case of non-compliance with the common foreign and security policy issues, non-compliance with EU statements is frequently perceived as politically dubious in Brussels. For example, in its questionnaire, the Commission requested Serbia to submit a list of EU statements it did not comply with (Marciacq and Sanmartín Jaramilloc, 2015, p. 204). Serbia's relations with Russia and concerns over Russia's efforts to establish and maintain influence in the Western Balkans is another key issue, especially for Poland and the Baltic States, which share borders with Russia (Baun and Marek, 2013, p. 210). Put differently, there are concerns among some Member States that, after Serbia's accession to the Union, Russia may use the position it has in this country to continue to pursue its policy within the EU. So, basically, it is a matter of the extent to which Serbia will be able to integrate into the EU Common Foreign, Security and Defense Policy, and support the Union's unique foreign policy measures and actions, given the limitations of its political and economic ties with Russia. This issue has become especially important and obvious after the EU imposed sanctions on Russia following the outbreak of the Ukrainian crisis.7

Considering the acquis in the field of the Common Foreign, Security and Defense Policy has evolved significantly in recent years, the issues related to the alignment of the policy of EU candidate countries in this field have become increasingly important and demanding. The extent and depth of changes in national foreign policies also depend on how different it is from the foreign policy of the Union. This is conditioned by the nature of the EU

\footnotetext{
${ }^{7}$ For more detailed information about the Ukrainian crisis, see: Jović-Lazić and Lađevac, 2017, pp. 112-141.
} 
candidate country's previous foreign policy views, its national interests and other country-specific factors. (Baun and Marek, 2013, p. 14). In some cases, the accession process requires far-reaching changes in the candidates' foreign policy, as it involves not only the adoption of the acquis in this area but also implementing additional and sometimes politically sensitive measures to bring their foreign policy in line with that of the Union. This includes, inter alia, the cancellation of all international agreements that fall under EU competence, as well as the acceptance of international obligations and the adjustment to EU restrictive measures and sanctions. Harmonization of EU candidate countries with EU pre-accession requirements is regularly monitored by the European Commission and the High Representative. On an annual basis, the European Commission publishes reports on the progress made by the EU candidate country on its path to the Union. These reports are divided into sections devoted to the progress and expectations that the EU has of the candidate country in each of the negotiation chapters individually.

Thus, candidate countries have a greater obligation to comply with EU standards in the field of the Common Foreign, Security and Defense Policy than the existing EU member states. Conditionality enables the Union to force the candidate country to change its foreign policy and ensure it becomes a functional member of the EU upon accession. This, as Christophe Hillion concludes, leads to a certain loss of autonomy of the candidate countries in creating their own foreign policy. However, given that the Member States continue to enjoy broad autonomy in the field of the Common Foreign, Security and Defense Policy, this indicates that once they become members, former candidates will have the opportunity to shape European norms, thereby gaining more autonomy in foreign policy, at least compared to its pre-accession situation (Hillion, 2017, pp. 265-268).

\section{ACHIEVEMENTS}

In Serbia's pre-accession negotiations with the European Union, the Common Foreign, Security and Defense Policy is covered by Chapter 31. This chapter is often classified as political and includes legally binding international agreements concluded by the European Union, EU Council decisions, restrictive measures, as well as political declarations and EU statements which the candidate must adopt or with which it must align its foreign policy. Explanatory and bilateral screening meetings were held in July and October 2014. They basically opened the process of critical 
assessment of the EU acquis in the area of CFSP/CSDP. However, more than five years later, the EU Council has not yet adopted the Draft of the European Commission's Screening Report on Serbia regarding Chapter 31. Without the Screening Report for Chapter 31, Serbia is not in full capacity to comply with the EU in this area. However, by analyzing the European Commission's annual progress reports, i.e., parts of the reports devoted to Chapter 31, information can be found what the EU considers as positive steps of Serbia and what as negative in this process.

Thus, the European Commission Reports state Serbia and the EU have a regular political dialogue regarding the issues covered by this chapter. Accordingly, a mechanism for consultation on the Common Foreign, Security and Defense Policy was established between the Ministry of Foreign Affairs of the Republic of Serbia and the European Foreign Policy Service (EEAS), and regular meetings are held at the regional level. Serbia has established an institutional framework to facilitate its participation in the Common Foreign, Security and Defense Policy and demonstrate a clear willingness to participate in EU crisis management missions. The legal basis for its participation in multinational operations is the Law on the Engagement of the Serbian Armed Forces and Other Defense Forces in Multinational Operations outside the Republic of Serbia borders, adopted in 2009. Moreover, in 2011, Serbia and the EU concluded the Agreement on Security Procedures for the Exchange and Protection of Classified Information and the Framework Agreement for Serbia's Participation in EU Security and Defense Missions, which sets out the general conditions for Serbia's participation in EU crisis management operations. Serbia ratified these agreements in February 2012, creating the preconditions for members of the Army and other defense forces of the RS, together with representatives of the Member States, to participate in EU-mandated multinational missions, which has a beneficial impact on the overall process of its European integration. Since 2012 and 2014, the Republic of Serbia has actively participated in EU military crisis management missions/operations under the Common Security and Defense Policy. Since 2012, members of the Ministry of Defense and the Army of the Republic of Serbia have participated in the European Union Naval Forces Mission (ATALANTA), the EU's Somali Security Force Training Mission (EUTM Somalia). Since 2014, Serbia has participated in the EU Security Force Training Mission of Mali (EUTM Mali) and the EU Military and Security Force Training Mission of the Central African Republic (EUTM RCA) (SR, 2019, pp. 91-93). 
Based on the European Commission's reports, it is clear the European Union greatly appreciates Serbia's participation in its peacekeeping operations. In recognition of Serbia's participation in the Union's operations and missions, Serbia has been given the opportunity to appoint a liaison officer to the EU Military Staff. The National Liaison Officer was appointed in November 2017, which was assessed as a step forward in strengthening relations, deepening cooperation, and establishing more effective communication in the area of the EU Common Security and Defense Policy. Also, the participation of the Serbian Armed Forces members and other defense forces in multinational operations outside the Republic of Serbia is in accordance with the national, security, defense, and foreign policy interests of the country. Thus, the Ministry of Defense is organizing training for officials from different sectors who will be able to participate in EU missions on behalf of Serbia (NPAA IR for 2018, 2019, p. 126). From 2017, Serbia also participates in EU battle groups, that is, in the EU HELBROC Battle Group. This group is led by Greece, with military units from Bulgaria, Romania, Cyprus and Ukraine. The note on Serbia's joining the technical agreement on founding the EU HELBROC Battle Group was signed on the sidelines of the meeting of the EU Military Committee held in November 2016, and the first engagement of the Serbian Army units is planned for the first half of 2020 (NPAA, 2018, p. 1221).

The development of the Republic of Serbia's capacity to participate in the Union's civilian missions is one of the important issues in Chapter 31, given that these missions are a crucial aspect of the EU Common Security and Defense Policy. EU civilian missions are established according to the United Nations Security Council resolutions and/or a decision of the EU Council, and their engagement is planned upon the needs and requests of the Union. Although there were no legal obstacles to the deployment of members of the military and other forces to multinational operations, the current legal framework did not envisage the deployment of civilian experts from Serbia to international civilian peacekeeping missions (Milenković \& Ignjatović \& Novaković, 2017, str. 49). To strengthen Serbia's capacity for participation in civilian missions, the Government of the Republic of Serbia adopted in May 2017 a Report on the need to establish a national legislative framework and institutional capacities for civilian participation in multinational operations. The Action Plan for Developing Civil Contributions of the Republic of Serbia to the EU, the OSCE and the UN Multinational Operations was adopted in June next year (NPAA IR for 2018, 2019, p. 126). Serbia is preparing a framework for participation in civilian missions under the CSDP, which includes, inter alia, the establishment of a 
national base of civilian experts for participation in national operations, under the mandate of the European Union, the OSCE and the UN. In 2018 and 2019, the institutions of the Republic of Serbia held several cycles of courses for civilian participation in multinational operations (NPAA IR for 2019, 2019, p. 121).

Also, Serbia is cooperating with the European Defense Agency. The legal basis for cooperation is the Administrative Agreement between the Ministry of Defense of the Republic of Serbia and the European Defense Agency of December 2013. Through this cooperation, realized within the framework of various projects, the adoption of the best European practice and effective integration of the Serbian defense industry into the European defensetechnological industrial base is expected. It should contribute, inter alia, to improving Serbia's military and defense capabilities by increasing the productivity of the domestic defense industry, the research potential of Serbian institutes, as well as technological modernization and preservation of its weapons and military equipment production (NPAA, 2018, p. 225).

As regards the prohibition of arms proliferation, arms control and arms exports, Serbia is included in some international export control treaties and anti-proliferation instruments, as mentioned in the European Commission Report. It has fulfilled its obligations under the Chemical Weapons Convention and developed an active legislative and administrative structure. In addition to the storage system, a national registry and database system for small arms and light weapons were created. Serbia ratified the Additional Protocol to the Safeguards Agreement with the International Atomic Energy Agency regarding the implementation of safeguards under the Non-proliferation Treaty in July 2018. The European Commission positively evaluates the fact that Serbia does not have bilateral immunity agreements which derogate from the jurisdiction of the International Criminal Court, and that it agrees with the EU common positions on the integrity of the Rome Statute, together with the relevant EU principles on bilateral immunity agreements. The European Commission also welcomes the fact that Serbia respects the territorial integrity and sovereignty of Ukraine and supports EU measures and documents for conflict prevention. (SR, 2019, p. 92). Serbia adopted a law on international restraint measures in 2016 to establish a legal framework for the application of international sanctions, which was one of the obligations of the negotiating Chapter 31.

Finally, it is important to note that the European Commission reports on Serbia for years 2012 and 2013 showed a high percentage of Serbia's compliance with EU decisions in the area of the Common Foreign, Security 
and Defense Policy. In the European Commission Report for 2012, Serbia's level of compliance with the EU policy in this area is estimated at $99 \%$. More specifically, Serbia joined the relevant declarations and decisions of the European Council in 69 out of 70 cases. It was then concluded that Serbia had significantly improved compliance with EU declarations and Council decisions in the area of the foreign, security and defense policy, and that alignment with the EU in this area was on the right path (SPR, 2012, pp. 6263 ). The Report adopted next year states that, when called upon to do so, Serbia complied with 31 of the 35 relevant EU declarations and decisions, which represents $89 \%$ compliance. It was further noted that, at the same time, Serbia had taken a step closer to the Collective Security Treaty Organization by obtaining observer status in its Parliamentary Assembly in April 2013 (SPR, 2013, p. 59).

\section{CHALLENGES}

Besides the aforementioned measures, which provided a visible degree of Serbia's compliance with the EU in the area of the Common Foreign, Security and Defense Policy and the fact that Chapter 31 is usually not too demanding, it has nevertheless become a particular challenge for Serbia. This was largely influenced by the Ukrainian crisis, having profound consequences on EU-Russia relations. In response to the annexation of Crimea and the destabilization of the neighboring sovereign country, the Union has introduced a series of restrictive measures against Russia. EU leaders canceled the Summit with Russia scheduled for June 2014. As part of the suspension of political relations, the EU Member States have decided to suspend regular bilateral summits with Russia. Bilateral talks on visas, a new EU-Russia basic agreement, as well as preparations for participation in the G8 Summit in Sochi, were also suspended. In addition, the Union froze the assets and banned travel to certain Russian and Ukrainian officials. Due to the situation in Ukraine, the EU has imposed far-reaching economic sanctions on Russia, to which Russia has responded with counter-sanctions.

Although the European Commission's Screening Report for Chapter 31 is the subject of closed debate between the Member States within the EU Council, it is speculated that Serbia's decision not to join the sanctions imposed on Russia because of the crisis in Ukraine represents a major obstacle to its adoption and further negotiations on this Chapter. In other words, as international relations have become more complicated, the 
Member States are trying to reach a consensus on certain issues within the EU in order to implement a unitary foreign policy.

The European Commission's 2014 Progress Report states that when invited, Serbia complied with 28 of 45 EU Council declarations and decisions in the area of the common foreign and security policy. This is a decline in compliance to $62 \%$ compared to $89 \%$ during the 2013 reference period of the Progress Report. Serbia generally supported Ukraine's sovereignty and territorial integrity, but the Report noted that it was absent from the vote on the UN General Assembly resolution on the territorial integrity of Ukraine. It further states that when called upon to do so, Serbia did not join the Council's decisions imposing restrictive measures in the context of the illegal annexation of Crimea to Russia and events in eastern Ukraine. The conclusion of this part of the Report emphasizes that Serbia's alignment with EU declarations and Council decisions in the area of foreign and security policy has significantly decreased compared to previous years and should be improved. (Serbia 2014 Progress Report, p. 61) These changes in the European Commission's assessment of the progress made by Serbia in Chapter 31 show that the Ukrainian crisis has affected Serbia's assessment as a candidate country.

Starting from 2015, the European Commission's annual Progress Reports on Serbia in the part regarding Chapter 31 clearly state that the Member States, besides conducting political dialogue in the context of foreign, security and defense policy, must be capable of joining EU declarations, participate in EU activities and apply agreed sanctions and restrictive measures. In this context, there is also a clear recommendation from the Commission that Serbia should implement its law imposing international sanctions, including restrictive EU measures, and monitor its implementation, as well as to advance the accession to EU declarations and Council decisions on the common foreign and security policy. The European Commission's 2015 Progress Report states that when invited, Serbia complied with 26 of 40 EU Council declarations and decisions. Considering the compliance percentage was $65 \%$, this is not a significant change from the previous year. As in 2014, Serbia did not comply with the Council's decisions, including restrictive measures imposed by the EU on Russia over the illegal annexation of Crimea and events in eastern Ukraine. However, as noted in this report, Serbia also did not comply with the Council's decisions on Bosnia and Herzegovina or Moldova (SR, 2015, p. 70). The European Commission's 2016 Report positively evaluated the fact that Serbia had adopted Law on Implementation of International sanctions in 
February, including restrictive EU measures. However, it is further stated that following already established practice, Serbia has not joined the Council's decisions involving restrictive EU measures relating to Russia or issues affecting Russia's interests. Besides, Serbia has not joined the Council's decisions on China, Bosnia and Herzegovina, Moldova and Zimbabwe. As a result, Serbia's accession rate regarding EU declarations and Council decisions in the area covered by Chapter 31, has dropped to around $59 \%$. It is further stated that in September and October 2016, Serbia did not join the EU decisions on South Sudan, Syria, and Burundi (SR, 2016, p. 80). The European Commission's 2018 Progress Report on Serbia reiterates that when Serbia was invited, it complied with 34 of 65 EU declarations and Council decisions, which represents an accession rate of close to $52 \%$. Among other things, Serbia did not join the EU restrictive measures against Russia and Ukraine. Besides, it is noted that Serbia has ratified the Co-operation and Joint Action Agreement between its Ministry of the Interior and the Russian Federal Security Service. The report recalled that 'Serbia has to ensure that the implementation of this agreement does not violate its obligations under the EU accession negotiations, which concern, inter alia, data protection and the exchange of classified information.' (SR, 2018, p. 85). The latest 2019 Annual Report of the European Commission reiterates that Serbia is expected to'improve alignment with EU declarations and Council decisions on the Common Foreign and Security Policy' and to apply the law introducing international restraint measures, including restrictive EU measures, and to monitor its implementation. Moreover, it is noted that Serbia has continued to fail to comply with EU restrictive measures that affect, inter alia, Russia and Venezuela. Serbia, when invited, complied with 46 of 87 relevant declarations and decisions of the Council, representing a compliance rate of close to 53\% (SR, 2019, p. 103).

The answer to the question why Serbia did not join the aforementioned EU declarations and measures can be found, among other things, in the National Program for the Adoption of the Acquis, adopted by the Government of the Republic of Serbia on the proposal of the Ministry of European Integration in 2018. As the primary reasons, this document states economic and political reasons. In doing so, it states, Serbia has maintained the consistent position it has had since the start of the SAA alignment process, meaning that 'all accession decisions are carefully considered, taking into account all state and national interests.' Therefore, the generally lower percentage of accession to EU declarations under the CFSP is a result of the fact that it is in the political and economic interest of Serbia to maintain traditionally good historical and cultural ties and relations with these 
countries, as well as with those who support the territorial integrity of the RS and act in accordance with such a position in the international forum. Thereby, our country recognizes that the support given by Russia and China as the permanent members of the UN Security Council is of paramount importance. In this document, we can also find an explanation that because of the cooling of EU-RF relations after the Ukrainian crisis, Serbia did not join a large number of declarations, whether political or imposed by restrictive RF measures. As noted, the reason is the fact that Russia is an important economic and political partner of Serbia and that any possible accession to EU sanctions would adversely affect its bilateral relations with Russia (NPAA, 2018, p. 1275).

Taking into account that since the escalation of the Ukrainian crisis, the level of adoption of EU regulatory acts in the field of the Common Foreign, Security and Defense policy is noticeably lower, Djukanovic points out that, although the political elite tries to maintain the illusion of intensive and good relations with both the EU and Russia, space for Serbia's maneuver is reduced. Because of the difficult social and economic situation and the dependence of the Serbian economy on the EU, this does not allow Serbia to develop, as an alternative, additional close relations with the Russian Federation (Đukanović, 2015, p. 88).

Closer cooperation with the EU in the area of CFSP/CSDP is in accordance with the Stabilization and Association Agreement, which is the basic legal document governing cooperation and relations between Serbia and the EU until accession. It envisages Serbia's readiness to align its position with the EU policy in various fields, including specific requirements for the Common Foreign, Security and Defense policy. Article 10 of the Stabilization and Association Agreement implies, inter alia, a greater approximation of the views of the parties in international matters, including those relating to the common foreign and security policy through the appropriate exchange of information, and in particular on matters that may significantly affect the parties. Besides, common positions on security and stability in Europe are envisaged, including cooperation in areas covered by the common external security and defense policy.

The Defense Strategy of the Republic of Serbia adopted in September 2019 states that the country's defense interest is to improve national security and defense through the process of European integration while respecting the specificities of the Republic of Serbia. It is further envisaged that this defense interest will be pursued by strengthening cooperative security with the EU, with particular attention being paid to strengthening individual 
security and promoting regional stability. It also expresses Serbia's commitment to hold security and defense consultations with the EU on issues of common interest, with the possibility of joint actions within the CSDP, which would be based on the common European values. In addition, it is emphasized that Serbia's participation in the CSDP activities is of particular importance for improving its national security and defense. It stresses that Serbia will continue to participate in EU military operations and civilian missions, and also intensify its participation in the organs and integrated structures of the common security and defense policy. It is further stated that the planning, preparation and operationalization of the participation of the Serbian Armed Forces and other defense forces in EU combat groups will continue, as it is assumed to be important for improving Serbia's national security and defense. Bearing in mind that both the military-neutral Union Member States and non-EU and NATO member states take part in this concept, it is concluded that Serbia's military neutrality is not an obstacle to its further integration into the EU (DSRS, 2019).

The National Security Strategy of the Republic of Serbia, also adopted in 2019, states that European integration and EU membership are Serbia's national interests and strategic orientation. This document states, among other things, that Serbia is 'firmly committed to contributing to the EU Common Foreign, Security and Defense Policy as part of the accession process, and to integrate into the concepts of that European policy'. It further states that Serbia 'endorses the European values and foreign policy objectives expressed in the basic documents of the European Union, as well as the main guidelines of its foreign policy actions based on those values.' (NSSRS 2019). The document stipulates that Serbia, in its foreign policy orientation, will strive to pursue a policy in accordance with the goals and principles set out in the EU Global Strategy for Foreign and Security Policy. It also states the participation of the military and civilian capacities of the Republic of Serbia in EU missions and operations is an important element of foreign policy, thus contributing to the world, European and regional security and respect of international law, and expresses its readiness to enhance mutual trust and shared responsibility in dealing with security challenges. Finally, it is indicated that under the Stabilization and Association Agreement and the Negotiating Framework, Serbia will continue to gradually align its foreign policy with the Union's positions in the period leading up to the EU accession. Therefore, at the time of membership, it will be fully harmonized with its foreign policy. Hence, from the above-stated, it follows that Serbia will support all initiatives in line with the EU Common Foreign, Security and Defense Policy in international 
relations. However, bearing in mind that the key Serbia's national interest is the preservation of sovereignty, independence and territorial integrity, it is necessary to focus on the part of the Strategy related to the national security policy which states that 'continuation of cooperation with key international actors and all Permanent Members of the UNSC is of strategic importance.' In doing so, the relations with China, Russia and the USA are particularly important. Based on these provisions of the Strategy, it can be concluded that in order to preserve territorial integrity and sovereignty, Serbia does not wish to support decisions, declarations and measures concerning the internal issues or important interests of the countries supporting Serbia's position on Kosovo and Metohija (Ibidem). Therefore, given the national interests of the Republic of Serbia and its complex position in contemporary international relations, it can be expected that adjusting to the European Union within the framework of the negotiating Chapter 31 will be a very demanding and complex challenge.

\section{CONCLUDING REMARKS}

Based on the official documents it has adopted, it should be certain that EU membership is one of the national interests of the Republic of Serbia. However, despite Serbia's officially declared willingness to align its foreign policy and security capacities with EU standards, as well as to lead external policy in line with the Union's positions, cooperation under Chapter 31 has become more complex. Although there is no screening report, it is possible to outline Serbia's commitments under this Chapter, based on the European Commission's annual reports on Serbia's progress towards European integration. In recent years, the percentage of alignment with the EU foreign policy declarations and measures has decreased. This is primarily due to the fact that after the Ukrainian crisis, relations between the European Union and the Russian Federation have deteriorated, which has made Serbia's position in international relations significantly complicated. Namely, the harmonization with the EU in the field of the common foreign and security policy has also started implying the imposition of sanctions on Russia, a traditional ally of Serbia, and one of the key international actors, who constantly and actively supports it in protecting its territorial integrity and sovereignty, which is the basic national interest of the Republic of Serbia.

Bearing in mind that Serbia maintains close relations with both the European Union and Russia, the further development of their relations will greatly influence Serbia's degree of alignment with the EU Foreign, Security 
and Defense policy. In this context, it will be important how permanent and unique the position in the Union itself will remain when assessing Russia's policy regarding the Ukrainian crisis. In any case, the further pace of Serbia's pre-accession negotiations will depend, first of all, on the further development of the international situation. This will certainly be influenced by the development of the situation at the national level as well, i.e., whether the country's basic directions and long-term foreign policy will remain unchanged. When conducting foreign policy, it should also be considered that some EU Member States see Serbia's policy of balancing between the European Union and Russia as an indication of future problems. So, basically, it is a matter of the extent to which Serbia will be able to integrate into the EU Common Foreign, Security and Defense Policy, and support the Union's unique foreign policy measures and actions, given the limitations of its political and economic ties with Russia. Although Serbia's position not to join certain restrictive EU measures is valid and understandable, I could agree with the opinions expressed in the Book of recommendations of the National Convent on the European Union that it should select one or two genuinely key points that it does not agree with, but should actively support all other activities and measures envisaged by the Common Foreign, Security and Defense Policy. In this context, it is stressed that the Republic of Serbia should analyze the declarations and measures with which it could have complied in the previous period, without jeopardizing its relations with those countries on which its key national interest probably currently depends. Besides, while it cannot affect the current international environment by improving bilateral relations with the EU Member States, Serbia can improve its position in EU negotiations. In this way, Serbia could reduce the potential negative effects of tensions that exist, primarily due to the Ukrainian crisis, between the European Union and the Russian Federation. On the other hand, the European Union and its Member States, by harmonizing their position on Serbia and providing a clear perspective on membership, could help to consolidate changes in the country. Therefore, the EU should create the conditions for Serbia to receive a screening report as soon as possible in order to focus on the issues covered by this Chapter and to encourage it to become more involved in cooperation within the EU Common Foreign, Security and Defense Policy. 


\section{REFERENCES}

Ateljević V. \& Forca B.\& Župac G. (2015). Opšti aspekt priključenja država Evropskoj uniji, [The general aspect of the accession of countries to the European Union], Vojno delo, Vol. 67, No. 3, pp. 108-109.

Barbé E. \& Morillas P. (2019). The EU global strategy: the dynamics of a more politicized and politically integrated foreign policy, Cambridge Review of International Affairs, Vol. 32, Issue 6, pp. 753-754.

Baun M. \& Marek D. (2013). The New Member States and the European Union: Foreign policy and Europeanization, Routledge.

Brommesson D. and Ekengren A. (2020). EU Foreign and Security Policy in a Mediatized Age, in: The European Union in a Changing World Order, Bakardjieva Engelbrekt, A., Bremberg, N., Michalski, A., Oxelheim, L. (eds.), pp. 193-195.

Davis Cross M. (2016). The EU Global Strategy and diplomacy, Contemporary Security Policy, Vol. 37, Issue 3, p. 402-404.

Đukanović D. (2015). The Process of Institutionalization of the EU's CFSP in the Western Balkan Countries during the Ukraine Crisis, Croatian International Relations Review, Vol. 21 No. 72, p. 88.

Đurđević-Lukić S. (2010). Deset godina Evropske politike bezbednosti i odbrane i promene ustanovljene Lisabonskim sporazumom. [Ten Years of the European Security and Defense Policy and the changes established by the Lisbon Treaty], Vojno delo, vol. 62, No. 4, pp. 28-48;

Hillion C. (2017). Adaptation for autonomy? Candidates for EU membership and the CFSP, Global Affairs, Vol. 3, No. 3, p. 265.

Jović-Lazić A. \& Lađevac I. (2017). Ukrainian Crisis as a Security Challenge of the Contemporary World, in: Social and Economic Problems and Challenges in the Contemporary World, Branislav Đordjevic, Taro Tsukimura, Ivona Lađevac (Eds.), Global Resource Management, Doshisha University, Japan, Institute of International Politics and Economics, Belgrade, pp. 112-141.

Jović-Lazić A. (2006). Evropski odbrambeni identitet u institucionalnoj strukturi Evropske unije i NATO, [European defense identity in the institutional structure of the European Union and NATO], Evropsko zakonodavstvo, br. 15/16, Institut za međunarodnu politiku i privredu, Beograd, pp. 89-103.

Jović-Lazić A., Lađevac I. (2008). Izgradnja bezbednosne strukture Evropske unije i NATO. [Building the security structure of the European Union 
and NATO], in: N. Jeftić (Ed.), Aktuelna pitanja iz međunarodnih odnosa, [Contemporary Issues in International Relations], Institut za međunarodnu politiku i privredu, Beograd, pp. 75-108.

Marciacq F. \& Sanmartín Jaramilloc N. (2015). When the European Union speaks on behalf of non-European Union states: a critical appraisal of the European Union's alignment mechanism in multilateral fora, European Security, Vol. 24, No. 2, p. 204.

Milenković D. \& Ignjatović D. \& Novaković I. (2017). Analiza nacionalnih kapaciteta za doprinos međunarodnim civilnim misijama, Beograd, [Analysis of national capacities for contributions to international civilian missions], retrieved from: https://www.isac-fund.org/wp-content/ uploads/2017/12/ANALIZA-NACIONALNIH-KAPACITETA-ZACIVILNE-MISIJE. pdf. Accessed: 17 November 2019.

Novičić Ž. (2010). Novine u spoljnoj i bezbednosnoj politici Evropske unije posle Ugovora iz Lisabona, [Innovations in the foreign and security policy of the European Union after the Lisbon Treaty], Medunarodni problemi, Vol. LXII, No. 3, pp. 397-417;

Prolović N. (2010). Lisabonski ugovor: institucionalne izmene u oblasti spoljne politike Evropske unije, [Lisbon Treaty: Institutional Changes in European Union Foreign Policy], Međunarodna politika, Vol. LXI, No. 1138, pp. $62-75$.

European Union. (2007). Treaty of Lisbon amending the Treaty on European Union and the Treaty establishing the European Community, signed at Lisbon, 13 December 2007 OJ C 306, 17.12.2007, retrieved from: https:/ / eur-lex.europa.eu/legal-content/EN/TXT/?uri=CELEX\%3A 12007L\%2FTXT, Accessed: 25 December 2019. (TEU)

European Union. (2012). Consolidated version of the Treaty on the Functioning of the European Union OJ C 326, 26.10.2012, retrieved from: https://eur-lex.europa.eu/eli/treaty/tfeu_2012/oj, Accessed: 25 December 2019. (TFEU)

European Union. (2016). Shared Vision: Common Action: A Stronger Europe. A Global Strategy for the European Union's Foreign and Security Policy, June, retrieved from: http:/ / eeas.europa.eu/archives/ docs/top_stories/pdf/eugs_review_web.pdf. Accessed: 20 December 2019. (EU GS)

European Union. Serbia 2012 Progress Report, Commission Staff Working Document, European Commission, Brussels, 10.10.2012, retrieved from: 
https://www.ecoi.net/en/file/local/ 1008763/1226_1350307531_serbia -rapport-2012-en.pdf. Accessed: 5 December 2019. (SPR, 2012)

European Union. Serbia 2013 Progress Report, Commission Staff Working Document, European Commission, Brussels, 16.10.2013, retrieved from: https:/ / ec.europa.eu/neighbourhood-enlargement/sites/near/files/ pdf/key_documents/2013/package/brochures/serbia_2013.pdf. Accessed: 7 December 2019. (SPR, 2013)

European Union. Serbia 2014 Progress Report, Commission Staff Working Document, European Commission, Brussels, 8.10.2014, retrieved from: https:/ / ec.europa.eu/neighbourhood-enlargement / sites/near/files/ pdf/key_documents/2014/20140108-serbia-progress-report_en.pdf. Accessed: 7 December 2019. (SPR, 2014)

European Union. Serbia 2015 Report, Commission Staff Working Document, European Commission, Brussels, 10.11.2015, retrieved from: https://ec.europa.eu/neighbourhood-enlargement/sites/near/files/ pdf/key_documents/2015/20151110_report_serbia.pdf. Accessed: 7 December 2019. (SR, 2015)

European Union. Serbia 2016 Report, Commission Staff Working Document, European Commission, Brussels, 9.11.2016, retrieved from: https://ec. europa.eu/neighbourhood-enlargement/sites/near/files/pdf/key_ documents/2016/20161109_report_serbia.pdf. Accessed: 7 December 2019. (SR, 2016)

European Union. Serbia 2018 Report, Commission Staff Working Document, European Commission, Strasbourg, 17.4.2018, retrieved from: https:/ /ec.europa.eu/neighbourhood-enlargement/sites/near/files/ 20180417-serbia-report.pdf. Accessed: 10 December 2019. (SR, 2018)

European Union. Serbia 2019 Report, Commission Staff Working Document, European Commission, Brussels, 29.5.2019, retrieved from: https://ec. europa.eu/neighbourhood-enlargement/ sites/near/files/20190529serbia-report.pdf. Accessed: 10 December 2019. (SR, 2019)

Izveštaj o sprovođenju Nacionalnog programa za usvajanje pravnih tekovina Evropske unije za četvrto tromesečje 2018. godine. (2019). Ministarstvo za evropske integracije, [National Programme for the Adoption of the Acquis Implementation Report for the fourth quarter of 2018]. (NPAA IR for 2018, 2019)

Izveštaj o sprovođenju Nacionalnog programa za usvajanje pravnih tekovina Evropske unije za drugo tromesečje 2019. godine. (2019). Ministarstvo za evropske integracije [National Programme for the 
Adoption of the Acquis Implementation Report for the second quarter of 2019]. (NPAA IR for 2019, 2019)

Knjiga preporuka Nacionalnog konventa o Evropskoj uniji 2017/2018. (2019). Evropski pokret u Srbiji, Beograd, 2019, [Book of recommendations of the National Convent on the European Union 2017/2018], (BRNCEU 17/18, 19)

National Programme for the Adoption of the Acquis -Third Revision (2018). Ministry of European Integration, February 2018, (NPAA), retrieved from: http://www.mei.gov.rs/upload/documents/nacionalna_dokumenta/n paa/third_revision_npaa_18.pdf. Accessed: 11 December 2019.

Strategija nacionalne bezbednosti Republike Srbije (2019). [National Security Strategy of the Republic of Serbia]. Narodna skupština Republike Srbije, Beograd, retrieved from: http://www.parlament.gov.rs/upload/ archive/files/lat/pdf/akta_procedura/2019/2206-19\%20-\%20Lat.pdf. Accessed: 14 December 2019. (NSSRS)

Strategija odbrane Republike Srbije (2019). [The Defense Strategy of the Republic of Serbia]. Narodna skupština Republike Srbije, Beograd, retrieved from: http://www.parlament.gov.rs/upload/archive/files/ lat/pdf/akta_procedura/2019/2207-19\%20-\%20lat.pdf. Accessed: 14 December 2019. (DSRS) 